\title{
EXPERT EVIDENCE: \\ The Ethical Responsibility of The Legal Profession
}

\author{
TANIA M. BUBELA*
}

The author examines the ethical obligations of the legal profession in using expert evidence. The author surveys developments in Canadian and U.S. jurisprudence, procedural and substantive issues, and law reform initiatives on the admissibility and use of expert evidence in civil and criminal litigation. She proposes a "tripartite framework" to address the use of expert evidence: by strengthening professional codes of conduct to address ethical obligations in using experts; byemphasizing lawyers 'obligations to improve the justice system; and by clarifying the criteria for admitting expert evidence.
L'auteur examine les obligations éthiques de la profession juridique quant à la preuve d'expert. L'auteur revoit les développements dans la jurisprudence canadienne et américaine, les questions de procédure et de substance et les initiatives de réforme de la loi sur l'admissibilité et l'utilisation de la preuve d'expert dans les poursuites civiles et criminelles. Elle suggère un " cadre tripartite " pour aborder l'utilisation de la preuve d'expert, à savoir le renforcement du code de déontologie dans le but d'aborder les obligations éthiques liées à la preuve d'experts. l'emphase sur le fait que les avocats ont l'obligation d'améliorer le système juridique et la clarification des critères qui permettent la preuve d'expert.

\section{TABLE OF CONTENTS}

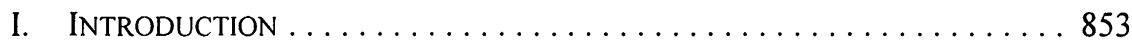

II. JUDICIAL RESPONSES TO EXPERT EVIDENCE $\ldots \ldots \ldots \ldots \ldots \ldots \ldots 855$

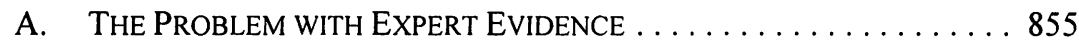

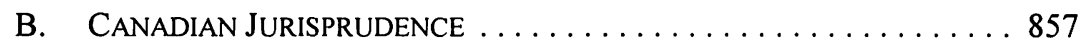

C. United STATES JURISPRUdENCE $\ldots \ldots \ldots \ldots \ldots \ldots \ldots \ldots \ldots$

III. LAW REFORM INITIATIVES ON EXPERT EVIDENCE $\ldots \ldots \ldots \ldots \ldots \ldots 860$

IV. ETHICAL DUTIES OF LAWYERS IN PRESENTING

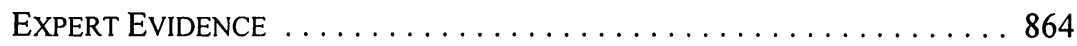

A. SUBSTANTIVE ISSUES: THE ISSUE OF ADMISSIBILITY

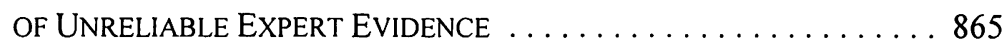

B. Procedural IsSUes: Cost AND EfFICIENCY $\ldots \ldots \ldots \ldots \ldots 86$

V. CONCLUSION ................................. 869

\section{INTRODUCTION}

Administration of justice in Canada, as in other common-law jurisdictions, is based on the adversary system.' Charles Wolfram notes in his treatise on legal ethics that the "assumption that underlies the adversarial system is that the mutually contentious strivings of relatively equal advocates will make truth and justice apparent to the judge and, if different, the fact finder."

Articling student; B.Sc. (Hons.), Australian National University, Canberra; Ph.D. University of Sydney; LL.B., University of Alberta.

William D. Barker, "A History of the Common Law and the Adversarial System in Canada" (1986) 5 Advocates' Soc. J. 6 at 11 .

2 Charles W. Wolfram, Modern Legal Ethics (St. Paul, MN: West Publishing, 1986) at 619. 
The adversary system has many failings. Reforms over the years have tempered the operation of the system in its pure form. ${ }^{3}$ Many of these reforms have focused on the issue of expert evidence. Expert evidence is utilized in matters requiring specialized or expert knowledge where the trier of fact may not have sufficient knowledge to draw the proper inferences from the evidence. ${ }^{4}$ In such instances, a witness who is an expert on the matters in issue is permittéd to state an opinion, an exception to common law rules of evidence that generally exclude lay opinion evidence.

The ethical duty of lawyers becomes more complex when scientific expert testimony is at issue, ${ }^{5}$ partly due to a fundamental disconnect between the processes of law and science. Scientific conclusions are subject to continual revision, and there may be a multitude of competing hypotheses on any one issue. The law, on the other hand, must resolve disputes quickly, efficiently, and finally on the basis of the best available evidence at the time of trial.

There are many problems for the administration of justice associated with the selection of experts and the use of expert testimony by opposing counsel in an adversarial setting. The problems may be grouped into two categories: substantive issues of justice and fairness, and procedural issues related to cost and efficiency. In the former category, the main concern is that a potential litigant will search far and wide for an expert prepared to express an opinion consonant with the case contended for by the client's lawyers." Trials thus become a "battle of the experts" with a technically untrained judge selecting between competing theories. In the latter category, the problem is the escalating costs and increased length of civil trials associated with the use by opposing parties of partisan or biased expert witnesses.

The partisan nature of expert witnesses in an adversarial system is a dominant issue both for the judiciary and for law reform initiatives in numerous common law jurisdictions. However, there is little focus on the ethical responsibility of the legal profession to temper the use of partisan experts or, for that matter, to support reform initiatives that may further the interests of the justice system over the interests of partisan advocacy. Here, I examine the responses of the judiciary and law reform initiatives to the use of expert evidence. I use the

(iavin Mackenric, "Breaking the Dichotomy Ilabit: The Adversary System and the I:thics of" Professionalism" (1996)9 ('an. J.L. \& Juris. 33 at para. 69. For more general discussions of the failings of the adversarial system, see Rudolph J. Gerber, Lawyers. Courts, and Professionalism: The Agenda for Reform (Wesport, C'): Greenwood Press, 1989); and Carric Menkel-Meadow, "The Limits of Adversarial Ethics" in Deborah L. Rhode, ed., Ethics in Practice: Lawyers' Roles, Responsibilities, and Regulation (Oxlord: Oxlord University Press, 2000) 123. Carric Menkel-Meadow, "The Trouble with the $\Lambda$ decrsary System in a Postmodern. Multicultural World" (1996) $38 \mathrm{Wm}$. \& Mary I. Rev. 5 at 6 said that the main critiques are: "Binary, oppositional presentations of lacts in dispute are not the best way for us to learn the truth; polarized debate distorts the truth, leaves out important information, simplifies complexity, and obfuscates rather than clarifies"; sec also Austin Sarat, "I:thics in I itigation: Rhetoric of C'risis, Realities of 'Practice" in Deborah 1. Rhode, ed., Ethics in Practice: Lawyers ' Roles, Responsibilities, and Regulation (Oxford: (Oxford University Press, 20)(0) 145. John Sopinka, Sidney N. Lederman \& Nlan W. Bryant, The L.aw of Evidence in Canada, $2 \mathrm{~d}$ ed. (Toronto: Butterworths, 1999) at para. 12.41.

Gerber, supra note 3 at 109.

Jason Borenstein, "Scientific I:xperts and the Courts" (200)1) XIV Professional l:thics Report I: and (icrber, supres note 3 at 109): "(ivil litigators regularly shop around for experts to support a partisan theory rather than aceept a neutral expert who speaks with objectivity. Some experts become professional testiliers, advertising their availability and pliability in legal journals. lawyers on both sides commonly call them "whores." 
term "questionable expert evidence" to refer to expert evidence that may not be admissible because it does not meet criteria of admissibility developed by the courts. ${ }^{7}$ I examine the role of the legal profession in furthering these reform initiatives, focusing on developments in Canadian jurisprudence, recent law reform initiatives in Alberta, ${ }^{8}$ and the application of the ('ode of Professional C'onducl of the Law Society of Alberta."

In interpreting the C'ode, the main issue with respect to expert evidence is a perceived conflict of duties. There may be a conflict in ethical obligations in the duties owed by lawyers to their clients and duties owed by lawyers to the court. The Code states that "[t]he duty of zealous representation... is seen to be subject to law and professional ethics and does not require a lawyer to follow the client's instructions regardless of circumstances." "It remains to be seen whether the provision of partisan experts is a duty to the client that outweighs a lawyer's professional and ethical obligation to the court in furthering the administration of justice both substantively and procedurally.

\section{JUIDICIAI, RESPONSES TO EXPERT EVIDINAC:}

\section{A. Tile Probigm witil Explikt Evidenc:}

For the most part, judicially-administered evidentiary standards have been the only means, albeit highly inefficient ones, of excluding questionable expert evidence from the courtroom. The judiciary has struggled with threshold questions of necessity, the qualification of experts, and criteria for determining admissibility. The courts have enunciated their concerns relating to the use of expert evidence by the legal profession through jurisprudence, extra-curial statements, and in surveys of the judiciary. "Recently, Binnie J. of the Supreme Court of Canada asserted that "the legal profession's "scientific illiteracy" is a growing problem because of the growing number of science-based disputes coming before the courts.... The judiciary also relies on trial lawyers to research an issue, but the files that are reaching the bench are often inadequate."/2

I use the term to be broader than, but to include, what has been referred to as "junk science." Issues of "junk science" and admissibility most commonly arise in the "soft" sciences such as the behavioural and social sciences where novel theorics may not be adeguately tested using aceepted scientilic methods, and may be unreliable due to minority acceptance within the expert community or lack of replication of results. The leading cases in the United States are: Denberl v. Merrill Dow Pharmaceuticals, 509) (1.S. 579)(1993) |1)auhert|: (i.t. v. Joiner, 522 U.S. 136 (1997) |.Jomer|: and Kumho Tire ('o. L.1d. v. ('armichael, 526 U.S. 137 (1990)) |Kiumho Tirel. The leading cases in ('anada are R. v. J.-I..J., |2000) 2 S.C. R. 600) [.J.J.| and R. v. Mohan, |1994| 2 S.C.R. $9 \mid$ Mohan|.

The Alberta Rules of C'ourt Project has just released a consultation memorandum for the legal profession in Alberta on the issue of expert evidence in civil matters: Alberta Rules of Court Project, Expert Evidence and "Independent" Medical lixaminations: Consultation Memorandum No. 12.3 (I:dmonton: Alberta Law Reform Institute, 2003), online: Alberta Law Reform Institute $<$ www.law.ualberta.ca/alri/pdfs/cnslt_memo/cm 12-3.pdis $\mid$ Consullation Memorandum| $\mid$. Version \# 2002-0) (November 2002) |ं'ode|.

lhid. at 2.

"Ian Ireckelton, "Judicial Attitudes Toward Scientilic I:vidence: "The Antipodean I:xperience" (1997) 30) U.C. Davis I. Rev. II.37 at 1216; and lan I'reckelton, Prasuna Reddy \& Ilugh Selby, Australian Judicial Perspectives on I:xpert l:vidence: An I:mpirical Study - Summary of Key lindings and Outcomes (The Australian Institute of Judicial Administration Incorporated), online: Australian Institute of Judicial $\wedge$ dministration Incorporated <www.aija.org.au/cxpsumm.doc> 
Expert evidence may canvas the physical and biological sciences, such as chemistry and genetics, ${ }^{13}$ or the behavioural ${ }^{14}$ and social ${ }^{15}$ sciences, or economics and accounting. ${ }^{16}$ Expert evidence may negatively impact the integrity of the trial process if excessive deference is shown to the opinion of the expert, thus undermining the promise of impartial adjudication. ${ }^{17}$

Contributing to the problem is the fact that the court may not hear opinions from the most qualified experts, but only from those most favourable to their respective parties, or from partisan experts who frequently appear for one side. ${ }^{18}$ The success of the testimony may depend more on the plausibility or self-confidence than on the professional competence of the expert. ${ }^{19}$ This distinction may be most evident during cross-examination. Crossexamination by opposing counsel may lead to the presentation of an inaccurate picture that may mislead the court and frustrate the expert. Indeed, Australian judges expressed a high degree of dissatisfaction with the quality of cross-examination of expert witnesses and the consequent adverse impact on the ability of the trier of fact to comprehend the evidence. ${ }^{20}$

It may also be difficult for a judge to weigh the evidence where there is a substantial disagreement concerning a field of expertise because the judge has no independent criteria by which to evaluate the opinions. ${ }^{21}$ Further, the adversarial system may not adequately distinguish between majority and minority views in the expert community and it may create a false impression of scientific controversy. ${ }^{22}$

All of the above concerns are substantive and related to the ability of the trier of fact to reach a fair decision based on the expert evidence. However, the judiciary is also concerned

P. Brad Limpert, "Beyond the Rule in Mohan: A New Model for Assessing the Reliability of Scientific Evidence" (1996) 54 U.T. Fac. L. Rev. 65.

Ron Nichwolodoff, "Expert Psychological Opinion Evidence in the Courts" (1998) 6 Health L.J. 279. Melvin M. Mark, "Social Science Evidence in the Courtroom: Daubert and Beyond?" (1999) 5 Psych. Pub. Pol. \& L. 175.

Dale V. Orlando, “The Battle of the Experts: Plaintiffs' Perspectives on Motions for Expert Assessments and Expert Testimony at Trial" The Advocates Society (10 January 2002) (QL) has stated that more than eleven experts may be called for a typical serious personal injury case: an accident reconstructionist, a computer animator to recreate how the collision occurred using computer animation, a human factors expert, a biomechanical engineer, the family physician who is treating the plaintiff, the treating specialists (orthopaedic surgeon, neurologist, neurosurgeon, neuropsychologist, and/or clinical psychologist), a functional capacity expert, a psycho-vocational expert, a future cost of care expert, a health care economist, and an accountant or actuary.

David M. Paciocco, "Coping with Expert Evidence about Human Behaviour" (1999) 25 Queen's L.J. 305 at 308.

Lord Woolf, Access to Justice: Final Report to the Lord Chancellor on the Civil Justice System in England and Wales (London: HMSO, 1996) at para. 6.75, online: Access to Justice - Final Report $<$ www.lcd.gov.uk/civil/final/contents.html> [Woolf Report]; Paciocco, ibid. at 311 . Woolf Report, ibid. at para. 6.75

Freckelton, supra note 11 at 1216; Freckelton, Reddy \& Selby, supra note 11. In 1999, all 478 judges in Australia were sent a questionnaire but judges without trial experience were asked not to respond. Fifty-one percent of judges (244) responded, although the response rate for judges with trial experience was closer to 60 percent. Sixty-five percent of judges responded that they encountered bias and partisanship on the part of expert witnesses occasionally and 26 percent encountered it often. Forty percent of total respondents said that partisanship was a significant problem for the quality of factfinding in their court.

$22 \quad$ Limpert, supra note 13 at para. 8. 
with cost and efficiency and, consequently, with equitable access to justice for the parties. There is concern that a party with greater resources may use expert testimony to overwhelm the evidence of the opposing party. ${ }^{23}$

The final concern is that science may be used to mislead legal decision makers if questionable theories that falsely exhibit the discourse and trappings of science are used to help validate and lend credibility to false or misleading statements. Indeed, Nichwolodoff argues that most evidence from experts in the behavioural sciences has not been developed and tested using, what is broadly accepted as the scientific method, namely the ability to falsify hypotheses. Such evidence, therefore, generally falls within the category of highly questionable expert evidence. ${ }^{24}$

\section{B. CanAdian JuRISPRUDENCE}

In response to concerns over questionable expert evidence, courts have placed limits on the use of expert evidence by adverse parties in litigation. The issue of necessity and reliability of expert evidence has been addressed by the Supreme Courts of Canada and the United States. ${ }^{25}$ The leading case on expert evidence in Canada is $R$. v. Mohan ${ }^{26}$ In later cases that have applied Mohan, the Supreme Court of Canada has emphasized that trial judges should take their role as gatekeepers seriously. ${ }^{27}$ Before expert opinion evidence is deemed admissible, the following four criteria must be satisfied. ${ }^{28}$

the expert opinion evidence must be reasonably necessary in the sense that it provides information likely to be outside the experience and knowledge of a judge or jury; ordinary people would be unlikely to form a correct judgment if unassisted by persons with special knowledge; its purpose is not to substitute the opinion of the expert for that of the trier of fact; ${ }^{29}$

- it must be relevant, which requires a finding of both logical relevance (it tends to prove a matter in issue) and legal relevance (its probative value outweighs its prejudicial effect) ${ }^{30}$

the evidence must emanate from a properly qualified expert; expertise is a modest status achieved when the expert possesses special knowledge and experience going beyond that of the trier of fact; ${ }^{31}$ and

Woolf Report, supra note 18 at para. 6.77 .

See Nichwolodoff, supra note 14.

Daubert, supra note 7: Joiner. supra note 7; Kumho Tire, supra note 7; J.J., supra note 7: and Mohan. supra note 7.

Ibid. In Mohan, the accused was a doctor alleged to have sexually assaulted a little girl. The defence expert attempted to suggest that because of the accused's sexual propensities, he was not the kind of person to commit the offences in question.

J.J., supra note 7: the accused was charged with a series of sexual assaults on two young boys. The defence contended that the offences were committed by someone who had a highly distinct personality disorder. A psychologist administered tests via a penile monitor to measure the accused's reaction to pedophilic pornography. The expert testified that the accused did not fit the profile of one who had the predisposition to commit the offences.

Mohan, supra note 7 at 21

J.J., supra note 7.

Mohan, supra note 7 at 22 .

R. v. Marquard, [1993] 4 S.C.R. 233 (QL). 
the expert evidence does not infringe an exclusionary rule such as the character evidence rules and the rule against oath-helping. ${ }^{32}$

Thus, if the trier of fact has sufficient expertise to resolve the factual issue, the expert opinion will not be admissible because it is not necessary. For example, in R.v. McIntosh, ${ }^{33}$ evidence from a psychologist that witnesses have problems of perception and recall when events are brief and stressful was held not to be outside the normal experience of the trier of fact. As a result, the psychologist's evidence was deemed inadmissible.

A court must also weigh the benefits of the evidence against its potential costs (probative value versus prejudicial effect). An important factor in assessing the benefit of the evidence is its reliability, including:

the extent to which the scientific theories on which it is based are accepted in the relevant scientific community;

the potential rate and nature of errors associated with a scientific technique relied upon; and

whether the scientific technique or theory has been tested via the scientific method.

The main cost is the prospect of uncritical acceptance of the opinion by the trier of fact. Especially:

if the scientific theory cannot be explained clearly;

if there is no realistic opportunity of an opposing party conducting independent tests or calling experts in reply or;

if the evidence could be presented in less conclusive or inflammatory terms than proposed.

Expert evidence that is based on a novel scientific theory or technique or on a technique that is used in a novel way ${ }^{34}$ is subjected to higher scrutiny in regard to both relevance and necessity. ${ }^{35}$ The court in $R$. v. J.-L.J. outlined the factors to be included in a contextual test for evaluating the reliability or soundness of novel science:

whether the theory or technique can be and has been tested;

whether the theory or technique has been subjected to peer review and publication; the known or potential rate of error or the existence of standards; and whether the theory or technique used has been generally accepted. ${ }^{36}$

Opposing counsel is entitled to cross-examine on questions of qualification and reliability, and may, of course, present an expert of its own with a countervailing view. The expert may be attacked on qualifications and discredited if found to be too partisan. The expert may also

Mohan, supra note 7 at 25 ; for a discussion of the character evidence rules and the rule against oath helping see: Sopinka, Lederman \& Bryant, supra note 4, paras. 10.1-10.120.

(1997), 35 O.R. (3d) 97 (C.A.).

J.J., supra note 7.

Mohan, supra note 7.

J.J., supra note 7 at para 33 . 
be questioned on the extent to which the scientific theories are accepted within the expert community, the potential rates of error associated with the techniques, procedures, diagnoses, or measurements relied upon, and whether the technique or theory has been tested via the scientific method.

\section{UNITED STATES JURISPRUDENCE}

In the United States, the Supreme Court has focused on the admissibility of expert evidence and screening processes that prevent unreliable expert testimony coming before a jury. The 1999 decision of the United States Supreme Court in Daubert v. Merrill Dow Pharmaceuticals ${ }^{37}$ and two further cases complete a trilogy of cases on expert evidence. ${ }^{38}$ In Daubert, the Court rejected the "general acceptance" standard stemming from Frye $v$. United States, namely, that the technique or theory had to have broad acceptance within the expert community in order to be accepted. ${ }^{39}$ Instead, judges were given a flexible mandate within the Federal Rules of Evidence $e^{40}$ to admit a wider range of expert testimony so long as it was reliable. ${ }^{41}$ Novel testimony should not be categorically dismissed even if it is not generally accepted in the expert community. However, Daubert drew an artificial distinction between scientific and non-scientific expert testimony, subjecting the former to judicial gatekeeping. In defending the role of judges as scientific gatekeepers, the Court reasoned:

[t]here are important differences between the quest for truth in the courtroom and the quest for truth in the laboratory. Scientific conclusions are subject to perpetual revision. Law, on the other hand, must resolve disputes finally and quickly.... We recognize that, in practice, a gatekeeping role for the judge, no matter how flexible, inevitably on occasion will prevent the jury from learning of authentic insights and innovations. That, nevertheless, is the balance that is struck by Rules of Evidence designed not for the exhaustive search for cosmic understanding but for the particularized resolution of legal disputes. ${ }^{42}$

In Kumho Tire Company v. Carmichael, the Supreme Court expanded the judge's gatekeeping function to all expert testimony. ${ }^{43}$ The admissibility factors described in Daubert gave the judge a broad discretion in weighing the merits of expert testimony, including:

whether it can be tested;

whether the theory or technique has been subjected to peer review and publication; the known or potential rate of error;

"general acceptance" can have a bearing on the inquiry; and

Supra note 7. In Daubert, the Court had to determine whether the anti-nausea drug Bendectin produced by Merril Dow Pharmaceuticals is a teratogen.

$38 \quad$ G.E. v. Joiner, supra note 7 and Kumho Tire, supra note 7.

293 F. 1013 (D.C. Cir. 1923).

U.S.C.S. Fed. R. Evid.

Craig Lee Montz, "Trial Judges as Scientific Gatekeepers After Daubert, Joiner, Kumho Tire, and Amended Rule 702: Is Anyone Still Seriously Buying This? (2001) 33 U. West. L.A. Rev. 87.

Daubert, supra note 7 at 593.

In Kumho Tire, supra note 7, the Court had to determine whether expert evidence from a tire manufacturer fell within the Daubert gatekeeping function. 
the existence and maintenance of standards controlling its operation. ${ }^{44}$

Since Daubert, American judges have functioned as active gatekeepers for the screening of unreliable expert evidence. The Federal Rules of Evidence $e^{45}$ that apply to expert evidence were amended in 2000 to incorporate the Daubert criteria. Courts now hold Daubert hearings, during which the admissibility of expert evidence is contested prior to trial or as part of the process of qualifying the expert during the trial. ${ }^{46}$ This procedure allows a judge to stop unreliable expert testimony going before a jury and at least one author has advocated that such hearings could be held on the admissibility of expert evidence in voir dires in civil trials in Canada. ${ }^{47}$ The criticism of such hearings is that they may disrupt and lengthen a trial, thereby increasing costs. In Alberta, civil trials are virtually never held before a jury, and the reliability of expert evidence still goes to the weight rather than to the admissibility of the evidence. Thus, judicial gatekeeping plays only a small role in civil actions in Alberta.

In summary, courts are concerned about the use of expert opinion evidence in the current adversary system. They have placed limits on the admissibility and use of experts in court proceedings with a view to both substantive issues of necessity and reliability and to procedural issues, such as length of proceedings, costs, and equal access to justice where resources may be disparate. While voir dires are commonly held to consider the admissibility of expert evidence in a criminal context, such hearings are rare in Canadian civil proceedings. ${ }^{48}$ Canada has not followed the United States model of pre-trial Daubert hearings to assess the admissibility of expert evidence. Unfortunately, the tests for reliability, as they are currently articulated set the threshold for admissibility relatively low and even though trial judges have been encouraged to act as "gatekeepers," it is likely that questionable expert evidence is still being admitted. Most pertinent to my thesis, by using the Mohan criteria, it is difficult for a lawyer to determine, prior to trial, whether expert testimony will be found to be inadmissible. The criteria are open to interpretation and may be applied differently by different trial judges, thus compounding the problem.

\section{LAW REFORM INITIATIVES ON EXPERT EVIDENCE}

It is obvious from the above discussion that courts are attempting to strengthen the evidentiary rules for expert evidence. However, it is not only the judiciary but the legal profession that must concern themselves with constructive and bona fide attempts to improve the justice system. The Code underscores that "[a] lawyer shares the responsibilities of all parties to society and the justice system and, in addition, has certain special duties as an

The Court clarified that the abandonment of the "general acceptance" test as the sole requirement for scientific testimony would not lead to a "free-for-all" of "irrational pseudoscientific assertions" (Daubert, supra note 7 at 595-96).

Supra note 40, r. 701-706 (2004) (as amended 1 December 2000).

David W. Eryou, “Why Isn't Daubert Being Used in Ontario Civil Cases?" Practical Strategies for Advocates IX (4-5 February 2000) 9; Michael H. Graham, "The Expert Witness Predicament: Determining "Reliable" Under the Gatekeeping Test of Duabert, Kumho, and Proposed Amended Rule 702 of the Federal Rules of Evidence" (2000) 54 U. Miami L. Rev. 317; and Montz, supra note 41. Eryou, ibid.

Ibid. 
officer of the court and by virtue of the privileges accorded the legal profession." ${ }^{\prime 49}$ In particular, "[a] lawyer should seek to improve the justice system." 50

Reforms may occur through legislative change, such as that which occurred in the United States when the Federal Rules of Evidence ${ }^{51}$ were amended to incorporate Daubert hearings to assess the reliability and admissibility of expert evidence. ${ }^{52}$ In Alberta, the Alberta Rules of Court Project is engaged in an endeavour to make positive changes, after consultation with the legal community and public, to the Alberta Rules of Court ${ }^{53}$ that govern expert evidence in civil actions. ${ }^{54}$ This same process is currently underway in a number of common law jurisdictions where the partisan nature of expert witnesses in an adversarial system is a dominant issue in law reform reports. ${ }^{55}$

The Rules relating to expert evidence are intended to promote pre-trial disclosure in order to prevent surprise at trial and a resulting disruption of the trial process but may not address some of the other concerns such as overly partisan experts. ${ }^{56}$ The proposed reforms focus on procedural matters, such as efficiency and cost of expert evidence and not the more complex substantive issues surrounding admissibility of expert evidence and the effectiveness of the adversary system as a whole. Some of the proposed reforms, however, may have the secondary benefit of tempering some of the excesses of the adversary system, mirroring reforms in other jurisdictions where there is a movement towards the less adversarial processes of court-appointed experts, referees, or advisors to the court. The function of such non-partisan experts is to provide advice to the trier of fact while treading the fine line of not usurping the trier of fact's role. Such experts are commonly used in civil law jurisdictions with an inquisitorial system. ${ }^{57}$ Justice Binnie supports the use of court-appointed experts as well as some of the more radical reforms in Australia with the same aim, such as panels of experts. $^{58}$

Code, supra note 9 at c. 1, Statement of Principle.

Ibid. at c. 1, r. 2.

Supra note 40.

Montz, supra note 41 ; see also supra note 45.

Alta. Reg. 338/83 [Rules].

Consultation Memorandum, supra note 8 at xi:

The Alberta Rules of Court govern practice and procedure in the Alberta Court of Queen's Bench and the Alberta Court of Appeal. They may also apply to the Provincial Court of Alberta whenever the Provincial Court Act or regulations do not provide for a specific practice or procedure. The Alberta Rules of Court Project (the Rules Project) is a 3-year project which has undertaken a major review of the rules with a view to producing recommendations for a new set of rules by 2004. The Project is funded by the Alberta Law Reform Institute (ALRI), the Alberta Department of Justice, the Law Society of Alberta and the Alberta Law Foundation, and is managed by ALRI.

See Australian Law Reform Commission, A Review of the Federal Civil Justice System, Discussion Paper 62 (August 1999), online: Australian Law Reform Commission <www.austlii.edu.au/au/ other/alrc/publications/dp/62>; Law Reform Commission of Western Australian, Review of the Criminal and Justice System: Final Report (1997-1999), online: <www.wa.gov.au/ Irc/RevCCJSp92/finalreport/finalreportpdf/ch22expert.pdf>; Law Reform Commission of Western Australian, Review of the Criminal and Justice System: Consultation Drafts Vol. 2 (1997-1999), online: Law Reform Commission <www.wa.gov.au/Irc/RevCCJS-p92/ConDrafts/3-3expertevid.pdf $>$; and Woolf Report, supra note 18 at para. 13.6.

Rules, supra note 53 at Part 15.

John H. Langbein, "The German Advantage in Civil Procedure" (1985) 52 U. Chicago L. Rev. 823. Tibbetts, supra note 12. 
There is an inherent tension in reform initiatives between the bench and the bar. Rules aimed at increasing the control over experts by the trial judges at the expense of the bar are unlikely to be supported by the legal community, despite reform obligations under the Code. This conflict is illustrated by some of the initiatives in Great Britain and Australia that seek to limit the involvement of legal counsel in the selection and instruction of expert witnesses. Such initiatives include pre-trial conferences with only the experts present that result, wherever possible, in a joint investigation and report that highlights areas of disagreement. ${ }^{59}$ Lord Woolf considered that ordering experts to meet was the most promising practice aimed at narrowing the issues between experts, with the added benefit of reducing costs by encouraging settlement. ${ }^{60}$ There may be a danger, however, that the party with more resources or more influential experts may overwhelm the conference. There may also be considerable tension between rival professionals. ${ }^{61}$ In Alberta, it was considered that any proposal that lessened the control of lawyers over their own experts would not be well received by the bar. ${ }^{62}$

Internationally, the trend is toward greater pre-trial disclosure, a reduction of or limits on the number of experts allowed to testify in civil trials, ${ }^{63}$ and practices that promote communication between experts prior to trial, such as early exchanges of expert reports. Promoting communication between experts will lead to an early identification of issues in dispute, resulting in greater efficiency and, possibly, in early settlement.

In Australia and other common law jurisdictions, there is a move towards emphasizing the duty of an expert to provide the court with complete, objective, and non-partisan information (including the limitations of the results or data). To this end, some courts have developed guidelines and codes of conduct that must be signed by the expert. If not signed, the report or oral testimony of the expert may not be admitted into evidence. The guidelines emphasize that the duty of an expert is to inform the court and not to be partisan. ${ }^{64}$ The inclusion of such guidelines within the Rules has been rejected, but optional guidelines that may be given to experts that emphasize the non-partisan duties of the expert to the court have been recommended. ${ }^{65}$

It may be more useful to encourage professional organizations to develop specific guidelines for their members when appearing as expert witnesses at trial. For example, the College of Physicians and Surgeons of Alberta has a brochure for its members who are System, Report No 89 (2000) at recs. 169, 172, online: ALRC <www.austlii.edu.au/au/other/alrc/ publications/reports/89> [Managing Justice].

Woolf Report, supra note 18 at para. 13.42.

Managing Justice, supra note 59 at rec. 62.

Consultation Memorandum, supra note 8 at 35.

Evidence Act, R.S.O. 1990, c. E-23, s. 12: "Where it is intended by a party to examine as witnesses persons entitled, according to the law or practice, to give opinion evidence, not more than three of such witnesses may be called upon either side without the leave of the judge or other person presiding." Managing Justice, supra note 59 at para. 6.96.

Consultation Memorandum, supra note 8 at 38. 
involved in either criminal or civil litigation. ${ }^{66}$ While this brochure is a useful overview of the legal process and the contractual relationship between the lawyer and the medical practitioner retained as an expert, nowhere does it mention ethical responsibilities of either the medical or legal profession. It does not state that the medical practitioner's primary responsibility is to be impartial and to inform the court and is not to the retaining lawyer or her client. In the United States, by contrast, both the American Medical Association and the American Psychological Association have the professional responsibilities and ethics of their members involved in litigation explicitly incorporated within their respective Codes of Conduct. ${ }^{67}$

Another method to promote objectivity is to encourage use of joint experts ${ }^{68}$ or, if the parties cannot agree on a joint expert, a court-appointed expert. The Holland Access to Justice in Medical Malpractice Group is a strong advocate for the use of joint experts in medical malpractice cases, particularly in relation to damages issues. In medical malpractice, typically between ten and 20 witnesses may testify. The reforms aim to "provide increased access to justice and equitable, affordable and timely resolutions." ${ }^{169}$ The Group recommends that plaintiffs and defendants in medical malpractice litigation retain joint experts on damages, recruited from the large number of experts whose experience, integrity, and opinions are respected by both sides. ${ }^{70}$

A more radical reform, the panel approach, ${ }^{71}$ has been adopted in some Australian jurisdictions. Expert witnesses are sworn in together and present as a panel, free to question each other and to be questioned by counsel. This approach has been found to be particularly helpful with economic or actuarial expert evidence.

w. See Rose M. Carter, Interaction Between Lawyers and Physicians in Litigation (Edmonton: Joint Medical-Legal Committee of the College of Physicians \& Surgeons of Alberta, Alberta Medical Association and the Law Society of Alberta, 2000).

See Justin P. Murphy, "Expert Witnesses at Trial: Where Are the Ethics?" (2000) 14 Geo. J. Legal Ethics 217.

Managing Justice, supra note 59 at para. 6.103; Woolf Report, supra note 18 at paras. 13.16-24; and Review of the Criminal and Justice System: Consultation Drafts, supra note 52 at 678.

(1) Holland Group, "Access to Justice in Medical Malpractice" (Fall 2001), online: Holland Group $<w w w$.thehollandgroup.org $>$.

lbid.

Managing Justice, supra note 59 at rec. 67. A panel presentation of expert evidence has generated significant efficiencies in the litigation process. The total time for considering expert evidence is considerably reduced whereas their contribution to the relevant court or tribunal is immediate. In the panel approach:

- experts submit written statements to the tribunal, which they may freely modify or supplement orally at the hearing, after having heard all of the other evidence;

$\because$ all of the experts are sworn in at the same time and each in turn provides an oral exposition of their expert opinion on the issues arising from the evidence:

- each expert then expresses his or her views about the opinions expressed by the other experts counsel cross-examine the experts one after the other and are at liberty to put questions to all or any of the experts in respect of a particular issue. Re-examination is conducted on the same basis.

This approach allows the testimony of all experts to be compared within a limited time frame as opposed to expert testimony being spread throughout the trial. Experts are less likely to be partisan and consider this procedure a "better way of informing the Court." Parties can still reserve the right to crossexamine witnesses. However, this method may not be appropriate in all circumstances as it can be "over-elaborate, too expensive and detract from the orderly and efficient presentation of opposing opinions" (ibid.). 
The Alberta Rules Project has adopted a number of the proposed novel reform options that will lead to enhanced flexibility for judges to control the presentation of expert testimony in the court room. These include minimum standards for the contents of expert reports ${ }^{72}$ best practice guidelines for experts with the caveat that they not be included in the rules, ${ }^{73}$ and the panel of experts ${ }^{74}$ Other reform options, however, were specifically rejected such as limiting the number of experts per issue per side. ${ }^{75}$ Rules to establish Daubert-style hearings were considered neither desirable nor necessary as, in Alberta, objections to expert evidence in civil actions on the ground of its being questionable are few. ${ }^{76}$ Other provisions that allow for the use of pre-trial conferences of experts (with counsel present), joint experts, and the appointment of experts or referees are already present in the Rules, but are rarely used. ${ }^{77}$

It may be that courts have sufficient powers to control and manage expert evidence, but do not always use these powers effectively. ${ }^{78}$ In many jurisdictions, flexible options are available, but are seldom utilized. Encouragingly, a survey of Australian judges indicated a preparedness of judges to "confront in a flexible way the difficulties posed by complex and conflicting evidence by experts." formulated to assist the Court in obtaining clear and objective expert evidence that is amenable to a sophisticated and cost-efficient analysis.

In summary, the legal profession under the Code has a duty to make constructive and bona fide efforts to improve the justice system in areas, such as expert evidence, where there are perceived weaknesses or injustice. Unfortunately, there may be a conflict between the bar and the bench in reform directions. The bench is concerned primarily with the admission of questionable expert evidence and the court must take seriously its role as gatekeeper. The bench is also concerned with issues of access to justice, attempting to streamline the cost and timelines of litigation. The bench ${ }^{80}$ and many commentators ${ }^{81}$ favour reforms that control the excesses of the adversarial system and place much of the control over expert evidence in the hands of the trial judge. There is a definite movement for the bench to become more inquisitorial and less passive in its decision-making. Unfortunately, few of these reforms are likely to be embraced by the bar that not only has a duty to court, but also to clients. These conflicting duties are discussed in the next section.

\section{ETHICAL DUTIES OF LAWYERS IN PRESENTING EXPERT EVIDENCE}

A common conception of legal ethics embraces the principles of partisanship and nonaccountability: "lawyers are justified in doing almost anything in their zealous pursuit of the interests of their clients, and that lawyers can act for the client whose actions and aims are

Consultation Memorandum, supra note 8 at 13 .

Ibid.

Ibid. at 37.

Ibid. at 21

Ibid. at 16

Rules, supra note 59 at Parts 15 and 15.1 .

Managing Justice, supra note 59 at para. 6.79.

Freckelton, Reddy \& Selby, supra note 11 at 9.

Tibbetts, supra note 12. See also Woolf Report, supra note 18

For example, see: Menkel-Meadow, "The Limits of Adversarial Ethics," supra note 3 at 130 
immoral without themselves being morally tainted by those actions." ${ }^{12}$ These two principles have contributed to "over-representation" in legal practice, in which "pressures to pursue client objectives compromise broader societal values." ${ }^{.83}$ I would add to this conceptualization that over-representation and the hiring of overly-partisan experts also compromises the administration of justice.

The Code acknowledges in its "Interpretation" section that a conflict may exist between a lawyer's duties to his or her clients and a lawyer's duties as an "officer of the court." 84 The Code makes the somewhat ambiguous assertion that "the rules are sufficiently specific that a conflict among ethical duties should not arise" ${ }^{85}$ but offers no explicit directions about in whose favour such conflicts should be resolved. The overarching conclusion must be, however, that a lawyer who acts in accordance with her obligations under the formal rules of professional responsibility cannot also act solely in zealous pursuit of the interests of her clients. ${ }^{86}$ Here I will analyze the sections of the Code that may have some relevance to the substantive and procedural issues on expert evidence.

\section{A. Substantive ISSUES: The ISSUE OF ADMISSIBILITY OF UNRELIABLE EXPERT EVIDENCE}

The judiciary has stated its concern over the necessity and reliability of expert testimony. The question is, to what extent do individual lawyers have an ethical duty to prevent unreliable expert evidence from entering the courtroom in the first place? Is it the role of the lawyer to screen potentially inadmissible evidence, or should that "gatekeeper" function be left to the court?

A lawyer has a duty to determine whether he believes expert testimony will be admissible before attempting to introduce such evidence ${ }^{87} \mathrm{~A}$ lawyer must not take steps in representing a client that are clearly without merit. ${ }^{88}$ This duty arises out of the lawyer's ethical obligation to represent a client resolutely and within the bounds of the law. ${ }^{89}$ To be an effective advocate, the lawyer must vigorously prepare for the presentation of facts and law and, in doing so, needs to test the accuracy and reliability of any testimony, including expert testimony, that he wishes to introduce. At the same time, as an officer of the court, the lawyer has a duty to the adversarial system of justice not to introduce frivolous or unreliable expert testimony:

Alice Woolley, "Integrity in Zealousness: Comparing the Standard Conceptions of the Canadian and American Lawyer (1996) 9 Can J.L. \& Juris. 61 at 62.

Deborah L. Rhode, "Institutionalizing Ethics" (1991) 44 Case W. Res. L. Rev. 665 at 666.

Code, supra note 9 at 2 .

Ibid.

Richard F. Devlin, "Normative, and Somewhere to Go? Reflections on Professional Responsibility" (1995) 33 Alta. L. Rev. 924; MacKenzie, supra note 3 at para. 40; and Woolley, supra note 80 at para.

27.

Code, supra note 9 at c. 10, r. 19: "A lawyer must not introduce or otherwise bring to the court's attention facts or evidence that the lawyer knows to be inadmissible."

Ibid. at c. 10, r. 1 .

Ibid. at c. 10, Statement of Principle: "When acting as advocate, a lawyer has a duty to advance the client's cause resolutely and to the best of the lawyer's ability, subject to limitations imposed by law or professional ethics. 
The Supreme Court of the State of Washington recognized this notion in stating: Vigorous advocacy is not contingent on lawyers being free to pursue litigation tactics that they cannot justify as legitimate. The lawyer's duty to place his client's interests ahead of all others presupposes that the lawyer will live with the rules that govern the system. ${ }^{90}$

Unfortunately, the Mohan criteria in Canada and the similar Daubert criteria in the United States do not provide a conclusive test for when expert testimony may or may not be found to be necessary and reliable and therefore admissible. The test under the Code merely states that:

knowledge that evidence is inadmissible may be imputed to the lawyer, if, under the circumstances, it would not have been reasonable for the lawyer to come to any other conclusion. However, [Chapter 10] Rule \#19 is not intended to prevent the introduction of evidence for which there exists a reasonable argument in favour of admissibility. ${ }^{91}$

It is likely, therefore, that only egregious examples of questionable expert evidence will be screened out by lawyers. In the current adversarial setting, it would be possible for a lawyer to argue that her decision to present expert evidence is reasonable and in the best tactical interests of her client's case. If the courts set no clear standards, then it may not be the ethical responsibility of the lawyer to define the inadmissibility of expert evidence. The inevitable conclusion is that if the threshold for admissibility is low, a lawyer may, under the "reasonable" standard embodied in the Code, introduce weak scientific evidence. It is equally difficult to determine how much time a lawyer should spend researching whether expert testimony is reliable before his actions are considered reasonable. The costs of such research would then be transferred to the client.

A potential risk is that an ethical lawyer who consciously foregoes questionable expert testimony that, if accepted, would further her client's interests will be placed at a disadvantage if confronted with a less scrupulous opponent. Clients may therefore be deprived of a level playing field if lawyers now undertake the task of screening out questionable expert evidence. Consequently, a lawyer may be discouraged from acting ethically at the risk of losing business in a highly competitive legal market.

Where should the line be drawn between ethically acceptable and unacceptable expert evidence? For example, should a lawyer reject, for ethical reasons, the testimony of a highly qualified expert with excellent credentials after discovering that she holds a minority opinion within her expert community? In such a situation, the lawyer would have a bona fide belief that the evidence would be admissible based on the qualifications of the expert. At least one ethics expert has said that the use of such testimony is not unethical. ${ }^{92}$

Washington State Physicians Ins. Exch. \& Ass' $n$ v. Fissons Corp., 858 P.2d 1054, 1084 (Wash. 1993) (en banc), as cited in Dick Thornburgh, "Junk Science- The Lawyer's Ethical Responsibilities" (1998) 25 Fordham Urb. L.J. 449 at 462.

" Code, supra note 9 at 68 .

'2 Thornburgh, supra note 90 at 466 : "Geoffrey Hazard has opined that, even if an attorney is aware that an expert's views are not respected by his or her colleagues in the field, hiring such an expert is not unethical." 
The Code prevents a lawyer from falsifying evidence or assisting a witness in doing so and from misrepresenting the identity of a witness. ${ }^{93}$ If a lawyer becomes aware that the court or another lawyer is under a misapprehension as a result of submissions made or evidence given, then the lawyer must immediately correct the misapprehension. ${ }^{94}$ This could affect expert testimony in two ways. First, it may forbid a lawyer from allowing an expert to testify as an expert in an area that is not scientifically valid. Second, it may forbid the lawyer from coaxing opinions from the expert that are beyond the realm of the expert's specialized knowledge (misrepresenting the expertise of the witness). Such coaxing would result in unreliable testimony (from the false claim of expertise), as the expert would be testifying in an area in which he possesses no expertise.

A general retort to the proposition that a lawyer has an ethical obligation to refrain from introducing questionable expert evidence is that the adversary system is designed to weed out unreliable evidence. Vigorous cross-examination, the presentation of contrary evidence, and careful instruction on the burden of proof are probably the most effective means for weeding out unreliable expert evidence. The question, as stated by the former Attorney General of the United States, Dick Thornburgh, is: "[w]hy should the lawyer advocating the position have to do his adversary's job by refraining from introducing evidence which is questionably reliable?" 95

He answers the question in the following manner:

One major problem with relying on the protections of the adversary system is that many times discussions take place during settlement negotiations, where the natural boundaries of the adversary system are not present. Lawyers can gain bargaining power by threatening to introduce junk science through qualified expert testimony. Take the example of the breast implant litigation. Dow Corning, the breast implant maker, agreed to a $\$ 4.25$ billion class action settlement in 1994 (including $\$ 1$ billion earmarked for lawyers) and filed for bankruptcy a year later. The manufacturer agreed to these concessions even though there had been no scientific evidence showing a causal connection between immune system disorder and silicone gel implants. ${ }^{96}$

Thus, in a settlement context, the adversary system is not sufficient to protect against the utilization of questionable expert evidence. In settlement negotiations, it should be unethical for lawyers to threaten to introduce questionable expert testimony. ${ }^{97}$ Under the Code, a "lawyer has a duty to deal with all other lawyers honourably and with integrity." lawyer must attempt to seek a resolution in accordance with the client's instructions, while protecting the confidentiality of that client, ${ }^{99}$ again his actions are subject to limitations imposed by law or professional ethics. ${ }^{100}$ If a lawyer were to adhere to his ethical obligations of not misleading the opposite party, ${ }^{101}$ that would help to prevent questionable expert

Code, supra note 9, c. 10, r. $13,14$.

$\mathrm{Ibid}$. at c. $10, \mathrm{r}$. 15 with respect to the court and Chapter 4 rules 1-2 for other lawyers.

Thornburgh, supra note 90 at 465 .

Ibid. at 466 .

Ibid.

Code, supra note 9, c. 4, Statement of Principle.

Ibid. at c. 7, r. 7.

Ibid. at c. 11, Statement of Principle.

Ibid. at c. 11, r. 1 . 
evidence from being improperly used as a sword in settlement negotiations. Further, threatening expert testimony that the lawyer is reasonably certain would be inadmissible in court borders on negotiating "an agreement that the lawyer knows to be criminal, fraudulent or unconscionable." 102

At present there are no sanctions that would hold lawyers accountable for introducing questionable testimony. The only possible consequences are loss at trial and the displeasure of clients at bearing the cost consequences of expert evidence that is found to be inadmissible or is rejected by the court at trial.

\section{B. Procedural Issues: Cost ANd EfFiciency}

Lawyers have a duty to make reasonable efforts to expedite the litigation process. ${ }^{103}$ Clearly, seeking out expert evidence that may later be found to be unreliable adds to both the cost and the length of the litigation process. Even calling large numbers of reliable, but overlapping experts may be contrary to this rule.

Lawyers should be expected to advise their clients with respect to the long-term costs that a particular legal tactic may produce. The role of the lawyer as advisor to a client is as important as the role of lawyer as advocate. A relevant ethical obligation of the lawyer is to "exert his best efforts to insure that decisions of his clients are made only after the client has been informed of relevant considerations.... In assisting his client to reach a proper decision, it is often desirable for a lawyer to point out those factors which may lead to a decision that is morally just as well as legally permissible."104

Realistic advice as to the cost of expert testimony may discourage many clients from pursuing expert opinion that would be of marginal assistance. Such advice is unlikely, however, to dissuade a client if the evidence is highly partisan and likely to further the client's case, especially if its admissibility is possible. However, a lawyer has no duty to implement instructions from a client that are contrary to professional ethics and is further obligated to withdraw if the client persists in such instructions. ${ }^{105}$ That being said, given the uncertainty of the law with respect to the admissibility of expert evidence, it is unlikely that following instructions from a client to introduce questionable expert testimony would contravene a lawyer's professional duties under the Code.

The rules limit the fees that experts can receive to reasonable compensation for their services. ${ }^{106}$ The expert may be paid for out of pocket expenses and loss of income as a result of appearing in court to testify. The reasonableness of such expenses must be balanced against the duty of the expert, as a citizen, to bear witness in a court of law and must be tempered by any appearance of impropriety.

Ibid. at c. 11, r. 4.

Ibid. at c. 10 , r. 2.

Thornburgh, supra note 90 at 464, citing the Model Code of Professional Responsibility EC 7-8 (1980).

Code, supra note 9 at c. 9, r. 10.

Ibid. at c. 10, r. 23. 
In contradiction of these stated values, the Rules then go on to explicitly condone the payment of contingency fees to experts so long as they are reasonable. ${ }^{107}$ This practice is not permitted under the Model Rules in the United States ${ }^{108}$ for obvious reasons. The practice is not permitted by the American Medical Association that, unlike the College of Physicians and Surgeons in Alberta, addresses the obligations of the medical profession to the administration of justice directly in its written code of conduct. ${ }^{109}$ An expert paid contingent on the outcome of a trial may be more likely to be partisan and to consider the client's interests over the duty that the expert owes as a witness to the court. On the other hand, contingency fees may make expert witnesses available to clients who could not otherwise afford an expert. On balance, the perception of bias would probably lead to serious questions of the credibility of such an expert. Fortunately, it appears that the practice of contingency fee payments is rare in Alberta. ${ }^{110}$

\section{Conclusion}

The reliability of expert evidence is of concern to the judiciary and to law reform initiatives throughout common law jurisdictions. The concern partly stems from the lack of accountability of "hired guns" that are available to testify on the basis of any theory, no matter how outlandish. However, partisan and dishonest experts may not be the root of the problem. A survey of expert witnesses from 128 criminal and civil trials found that 77 percent of expert witnesses felt pressured by the lawyer dealing with the case to strengthen favourable evidence and place less emphasis on unfavourable evidence. ${ }^{\prime \prime}$ Fifty-seven percent of experts were also urged to be less tentative. ${ }^{1 / 2}$

Within the confines of the adversary system, courts have placed limits on the admissibility and use of experts in court proceedings. The criteria used by the courts to assess admissibility focus on the substantive issues of necessity and reliability. The secondary concern, also addressed by law reform initiatives relates to procedural issues, such as length of proceedings, costs, and equal access to justice where resources to hire experts may be unequal between opposing parties.

There are some differences between the United States and Canadian models, mostly due to the greater use of juries in civil trials in the United States. Canada has not followed the United States model of Daubert hearings to assess the admissibility of expert evidence. In Canada, the use of voir dires to consider the admissibility of expert evidence is only common in criminal proceedings. ${ }^{113}$

Unfortunately, the test for reliability in Canada sets the threshold for admissibility relatively low and even though trial judges have been encouraged to act as gatekeepers, it is likely that questionable expert evidence is still being admitted. The criteria are open to

Ibid. at c. 10, r. 23, comment 23.

Murphy, supra note 64 at 229.

Ibid. at 231 .

The Alberta Civil Trial Lawyers Association considers that contingency fees for experts are not common. of Expert Witnesses in the Courts" (1994) 34 Jurimetrics 193 at 208. 
interpretation and may be applied differently by different trial judges. Thus, it is difficult for a lawyer to determine, prior to trial, whether expert testimony will be found to be inadmissible.

Given the current state of the law, there may be no simple answer for the legal profession. "It is no longer sufficient to cite the advice of that great New York lawyer, Elihu Root, who once opined: About half of the practice of the decent lawyer consists in telling would-be clients that they are damned fools and should stop." 114 This admonition loses much of its force when placed in the context of the plethora of hard and soft scientific theories that are available to support a client's position.

There may be a workable tripartite framework within which to approach the ethical dilemma of a lawyer in dealing with potentially conflicting obligations to the court and to the client. First, the Code must be strengthened to explicitly incorporate provisions on expert evidence beyond questions of remuneration. It should be fully recognized within the Code that a lawyer has a professional obligation to carefully scrutinize the integrity of her own expert's proposed testimony within the limits of her capacity and resources. Contingency fees for experts should not be condoned.

Second, lawyers' obligations to improve the justice system should move beyond partisan wrangling with the bench over control of expert testimony. The legal profession should embrace the move away from a purely adversarial system to a more inquisitorial model. There should be enforceable sanctions under the Code of cost consequences available under the Rules of Court to ensure that opposing counsel act in a similarly ethical manner by presenting only bona fide expert scientific theories. This will dispel the concern that a lawyer who acts ethically may jeopardize his case against an unethical opponent.

Finally, as a cap to this process, the court should clarify the criteria for admitting expert evidence, perhaps following the lead of the United States of Daubert-style hearings so that a practitioner can assess the admissibility of expert testimony prior to trial. This would also require procedural amendments to the Rules. However, at present, trial judges should be creative and use the flexibility currently available in the Rules when dealing with expert evidence. The court should embrace current reforms to the procedural rules governing expert evidence that increase its power to control expert testimony, even though such reforms are less well received by the legal profession. The court should not hesitate to refer disputes over alleged questionable expert evidence to non-partisan or court appointed experts, not to decide the question in controversy, but to assess the quality of the expert opinion evidence, thereby exercising the "gatekeeping" function that has been articulated by the Supreme Court of Canada.

Lawyers from opposing sides of a particular case, judges, and experts must begin to take their obligations to the legal system, within which they all operate, much more seriously. In an era of vast and rapid scientific and technological advances, reform is a necessary burden that must be embraced by all involved in advancing and preserving the rule of law. 